\title{
Morphological and ecological peculiarities of checker tree mountain ash (Torminalis glaberrima) plants and biochemical composition of its fruits
}

\author{
T. Z. Moskalets*, A. H. Vovkohon**, Y. M. Barat***, O. V. Knyazyuk****, P. N. Verheles***** \\ *Institute of Horticulture of the National Academy of Agrarian Sciences of Ukraine, Kyiv, Ukraine \\ **Bila Tserkva National Agrarian University, Bila Tserkva, Ukraine \\ ***Poltava State Agrarian Academy, Poltava, Ukraine \\ ****Vinnytsia Mykhailo Kotsiubynskyi State Pedagogical University, Vinnytsia, Ukraine \\ *****Vinnytsia National Agrarian University, Vinnytsia, Ukraine
}

Article info

Received 24.05.2020

Received in revised form 07.07.2020

Accepted 08.07.2020

Institute of Horticulture of the National Academy of Agrarian Sciences of Ukraine Sadova st., 23, Novosilky, Kyiv region 03027, Ukraine. Tel.: +38-044-526-65-48 E-mail:shumyascience@ukr.net

Bila Tserkva National Agrarian University, Soborna sq., 8/1, Bila Tserkva, 09117, Ukraine Tel. : +38-045-635-25-87. E-mail:alinavovkl@ukr.net

Poltava State Agrarian Academy Skovorody st., 1/3, Poltava, 36003, Ukraine. Tel.: +38-053-250-02-73 E-mail:ybarat@ukr.net

Vinnytsia Mykhailo Kotsiubynskyi State Pedagogical University, Ostrozkoho st., 32, Vinnytsia, 21100, Ukraine. Tel.: +38043-226-52-20.E-mail:vin kov@ukr.ne

Vinnytsia National Agrarian University, Solnyschnaya st. 3, Vinnytsia, 21008

Ukraine. Tel.: +38-043-226-51-10. E-mail:pasha425@vsau.vin.ua

\begin{abstract}
Moskalets, T. Z., Vovkohon, A. H., Barat, Y. M., Knyazyuk, O. V., \& Verheles, P. N. (2020). Morphological and ecological peculiarities of checker tree mountain ash (Torminalis glaberrima) plants and biochemical composition of its fruits. Regulatory Mechanisms in Biosystems, 11(3), 405-413. doi:10.15421/022062
\end{abstract}

The selection and comparative study of new forms of the Red Book species checker tree mountain ash (Torminalis glaberrima (Gand.) Sennikov \& Kurtto) were conducted on the basis of generalizing the literary data and expeditionary research on the natural and local gene pool of the above-mentioned plant. Information was presented about the peculiarities of the selection and valuable forms of the checker tree concerning the indices of vitality and morphology in the Central, South-Western, and Western Forest-Steppe of Ukraine. These forms appeared to be characterized by high vigour (over $30-40 \mathrm{~cm}$ ), large size and mass of the fruits (1.7-2.4 g), their increased nutritional value, high ecological plasticity and ornamentality (crown shape, leaf colouration and shades during the growing season). Taking into consideration the ornamental characteristics, the selected forms are rather promising in landscape construction and phytodesign as complementary elements of oak-beech, oak-hornbeam and other species associations, as well as green corridors of the ecological network. This will contribute to the restoration and preservation of this rare species, thus facilitating restoration, spreading and conservation of this rare species, thereby increasing the stability of ecosystem components, squares, alleys, nature-conservation territories and enhancing the aesthetic qualities of the gardens when establishing harmonious landscape compositions. The fruits of $T$. glaberrima are characterized as raw material for processing and manufacturing of medicinal preparations and food products. The biochemical analysis of the checker tree mountain ash berries has shown that they are characterized by high content of a number of biologically active substances: polyphenolic compounds, flavonoids, vitamin C. The wide use of the checker tree will enable the food and pharmaceutical markets to be supplied with medicinal and fruit raw material by its introduction into new cultivation conditions, namely: into industrial and ornamental horticulture, forestry. The new genotypes of $T$. glaberrima were selected and are planned to be transferred to the National Centre for the Plant Genetic Resources of Ukraine. That will make it possible to replenish the genetic bank of Ukraine with representatives of the species, which are promising in fruit growing and ornamental horticulture, forestry and nature conservation.

Keywords: wild service tree; new genotypes; selection principles; evaluation system; vitality indices; genetic resources.

\section{Introduction}

In 1992 the UN conference took place in Rio de Janeiro dedicated to environmental problems. The main attention was devoted to ensuring sustainable and permanent biodiversity. The diversity of wildlife is an indicator of the stability of ecosystems (Moskalets \& Rybalchenko, 2016; Bednorz \& Nowinska, 2018) and provides a functional relationship between communities, supports the passage of biogeochemical processes in the biosphere at the appropriate level (Paul et al., 2000; Krynytskyi et al., 2017). Today the processes of the species disappearance and ecosystem degradation have acquired a mass character (Dines et al., 2005; Lefèvre et al., 2020), therefore biodiversity conservation is one of the key tasks of modernity (Coetzee, 2017). Change in the natural conditions and anthropogenic activity have caused a decrease in range, and alterations in the functional organization of many plant species (de Rigo et al., 2016; Bednorz \& Nowinska, 2018). Most threatened plants are rare, endemic or ed- ge of range (Krynytskyi et al., 2017). They are represented mostly by isolated populations, which differ in genetic and ecological structure, tied to certain habitat types that are separated from each other by geographic or biological barriers (de Rigo, et al., 2016; Hallmann et al., 2017).

One of the unique species of the plants in the gene pool of Ukraine and Europe is the checkertree mountain ash (Torminalis glaberrima (Gand.) Sennikov \& Kurtto) (Demesure-Musch \& Oddou-Muratorio, 2004; Hoebee et al., 2006; Ulaszewski et al., 2017; Shpak, 2018; Grynyk et al., 2019). Its environmental status in Ukraine has not been valued yet (Didukh, 2009). In the Carpathians, Crimea, this species grows in rock-oak and rock-oak-pine forests and is common in the middle mountainous belt (Kosets, 1941; Gordiyenko, 2007; Shpak, 2019). The reduction in the number of the species is brought about by felling of mixed deciduous forests (Aas \& Kohles, 2011), their replacement by monocultures, selective felling of the checker tree mountain ash as valuable wood for the production of musical instruments, furniture (Termena \& Budzhak, 1997; 
Grynyk et al., 2019). Checker tree mountain ash, or checker tree, or wild service tree, or Sorbus torminalis (L.) Crantz, 1763, or Torminalis glaberrima (Gand.) Sennikov \& Kurtto, 2017 (Sorbus glaberrima Gand. 1875= Sorbus torminalis f. glaberrima (Gand.) Hegi 1923) - is a tree or shrub of temperate deciduous forests. The very complicated synonymy of this species has been summarized by Sennikov \& Kurtto. They have also presented a detailed list of the homotypic synonyms of the Linnaean name Crataegus torminalis L. (Sorbus torminalis (L.) Crantz, $1763=$ Mespilus torminalis (L.) F. H. Wigg. $1780=$ Pyrus torminalis (L.) Ehrh. $1791=$ Hahnia torminalis (L.) Medik. $1793=$ Lazarolus torminalis (L.) Borkh. $1798=$ Azarolus torminalis (L.) Borkh. $1803=$ Pyrenia torminalis (L.) Clairv. 1811 = Pyrus septiloba Stokes, 1812, nom. illeg. superfl. = Malus torminalis (L.) Risso, $1826=$ Torminaria clusii M. Roem. 1847, nom. illeg. superfl. $=$ Torminaria vulgaris Schur, 1866, nom. illeg. superfl. $=$ Aria torminalis (L.) Beck, 1892 = Torminaria torminalis (L.) Dippel, 1893 = Torminalis clusii K. R. Robertson \& J. B. Phipps, 1991 (Moskalets et al., 2020; Sennikov \& Kurtto, 2017).

This species belongs taxonomically to the phylum (series) Tracheophytes, order (row) Rosales, family Rosaceae, subfamily Amygdaloideae, tribe Maleae, subtribe Malinae, genus Torminalis Medik (Grynyk et al., 2019; Moskalets et al., 2020). The species name $S$. torminalis originates from the Celtic word 'sor' - 'tart' or from Latin 'sorbere' - 'absorb' or from Latin 'torminalis', 'tormina' - 'intestinal colic' or, perhaps, from the Greek 'torminalis' - 'soothes abdominal pain', because the fruits of checker tree have long been considered as an auxiliary means of the treatment of people with dysentery (Kosets, 1941; Gaivelyte et al., 2014).

T. glaberrima is one of the valuable woody species growing in Ukraine. Its wood is hard, silky, with a fiery shade, used for manufacturing high-quality precious furniture, elegant wooden items, and its branches and leaves are nutrients favoured by the forest fauna (Aas \& Kohles, 2011; Bednorz \& Nowinska, 2018). Wild service tree is valued as an ornamental culture in parks, squares and alleys thanks to the ornamentality of the crown, fine colouration of the leaves, particularly in autumn. Unfortunately, this plant is less common in forestry plantations, except for certain forestries, for example, Brytavsk, Dokhniansk, Chervonohrebelsk, and Stratiiv in the Southern Podillia Forest-Steppe of Ukraine where its area is about 40 hectares (Budzhak et al., 2000; Shpak, 2019).

One of the types of plant biodiversity conservation is legal protection of the species populations, range distribution ('Red Book of Ukraine', Green Paper, International List of Plants, environmental protected areas) and plant genetic resources through cultivation of specific varieties of plants in the form of a variety (sort, cultivar). In order to preserve the checker tree mountain ash, which is a disappearing species in Ukraine, both monitoring and identification are important. The localizations of its populations and the selection of individual genotypes which differ in the complex of valuable vitality indices are significant. The search, observation, identification, collection and comparison of the experimental and literature data on morphological and ecological peculiarities of the species will facilitate the generalization of the obtained data. It is precisely this which has determined the purpose and tasks of our research, namely: to investigate morphological indicators and ecological peculiarities of natural and seminatural checker tree populations, select among them certain genotypes for vigour signs, large size and mass of fruits, high ecological plasticity and ornamentality and to carry out the biochemical analysis of the fruits.

\section{Materials and methods}

Materials were conducted in the Western, South-Western ForestSteppe (Western Ukrainian Forest-Steppe Province) and Central ForestSteppe of Ukraine (Dniester-Dnieper Forest-Steppe Province). The monitoring explorations and observations of the checker tree population status and separate plantations were conducted in 2017-2020, namely: Kamianets-Podilskyi district (not far from the village Suprunkivtsi, Khmelnytskyi region, $48^{\circ} 44^{\prime} \mathrm{N} 26^{\circ} 45^{\prime} \mathrm{E}$ ), the town Kamianets-Podilskyi (Khmelnytskyi region, $48^{\circ} 25^{\prime} \mathrm{N} 26^{\circ} 32^{\prime} \mathrm{E}$ ), the village Skala Podilska (Ternopil region, $48^{\circ} 51^{\prime} \mathrm{N} 26^{\circ} 11^{\prime} \mathrm{E}$ ), the Kremenets Botanical Garden (Ternopil region, $50^{\circ} 05^{\prime} \mathrm{N} 25^{\circ} 43^{\prime} \mathrm{E}$ ), not far from the village Myroliubivka (Pishchanka district, Vinnytsia region, $48^{\circ} 13^{\prime} \mathrm{N} 28^{\circ} 49^{\prime}$ E). The experimental research (biometric measurements, analytical investigations, mathematical and statistical processing of the experimental data) was carried out at the Institute of Horticulture of the National Academy of Agrarian Sciences of Ukraine and the Bila Tserkva National Agrarian University.

The study of the checker tree plant populations was conducted according to the accepted methods (1986), and phenological observations over the plants' growth and development as well as the biometric indicers were carried out in accordance with the methods of Beydemann (1974). The dynamics of the shoots growth and development, periods of the establishment and formation of generative organs, buds and leaves were explored in conformity with the accepted methods (Tkachyk, 2016). The qualitative and quantitative characteristics of buds, shoots, inflorescences, flowers as well as of leaves and fruits were analyzed, pre-selecting 25 inflorescences and 25 leaves on each of the four sides of a tree. The total sample of leaves, inflorescences was 100 . Shoots for the research were selected from the middle part of the crown. In the assessment of plant yield and seed productivity the weight method, forming the total fruit sample $(1 \mathrm{~kg})$ of which 100 fruits were selected to establish the qualitative and quantitative characteristics. 43 genotypes were discovered and selected in the Central, South-Western, and Western Forest-Steppe of Ukraine as a result of the expeditionary research on the natural and local gene pool of the above-mentioned checker tree plants. Plants of different ontogenetic periods: latent, virginal (juvenile and immature), generative, postgenerative (senile) were analyzed in order to identify differences in the morphological signs and biological peculiaitives.

The morphological characteristics were identified by means of the visual assessment and measurements or calculations depending on the type of their detection. The identification of the morphological signs was carried out on immature (Im), young vegetative (V1) and generative plants. The morphological characteristics, their codes and subcodes were used to in order to assess the detection of the distinctiveness and uniformity in keeping with the accepted methods (Tkachyk, 2016), namely: rest period (complete leaf fall or before the beginning of the spring sap flow); the beginning of the vegetation (swelling of the vegetative buds); the budding of generative buds, the beginning of flowering (5-10\% flowers opened on the tree); flowering ( $\geq 50 \%$ of the flowers are opened); growth of shoots (full disclosure and formation of the leaf blade); fruits growth and formation; fruits technical and consumption ripeness ( $\geq 50 \%$ fruits on the tassel).

The protection status of T. glaberrima was established according to the 'Red Book of Ukraine' (Didukh, 2009) and the International Union for the Conservation of Nature (IUCN) Red List database (Rivers et al., 2019). The dry substances' (solids) content was determined applying the weighted method in keeping with SSU 7804:2015; sugars - using the photocolorimetric method on the photocalorimeter KFK-3-01 (SSU ISO 4954:2008); organic acids - by titration with $0.1 \mathrm{n} \mathrm{NaOH}$ in the recalculation for the malic acid in accordance with SSU 4957:2008; of vitamin $\mathrm{C}$ to restore the Tillmans reagent, by extraction of the fruits batch with the acid solution with the further filtration of the obtained substrate using the titrometric method in conformity with SSU 7803:2015; the polyphenolic compounds - amount utilizing the Folin-Dennis reagent spectrophotometric method on the spectrophotometer Spekol 1500 at the wavelength of $270 \mathrm{~nm}$ with a photometric accuracy of 0.004 (SSU ISO 4373:2005). The sugar-acid index (SAI) was calculated as the correlation of total sugars and acids. The biochemical analyses were conducted in the 3 fold repetition in each variant of the experiment.

The differences between the researched variants' values in the control and experimental groups were established using ANOVA, where the differences were considered significant at $\mathrm{P}<0.05$ (with Bonferroni correction). The average value of the standard error $(\mathrm{x} \pm \mathrm{SE})$ was determined.

\section{Results}

43 checkertree mountain ash genetic types were revealed and selected as a result of the expeditionary inspections of the anthropic and natural ecosystems of the Central, South-Western, and Western Forest-Steppe of Ukraine. Most of the generative plants in the studied habitats have a height of up to $15 \mathrm{~m}$, and are thus classified as medium-sized, in particular, these are the forms 'Slavka', 'Kyianochka' and height more than $15 \mathrm{~m}$ ('Prydnistrianka', Form 1-18-205, Form 1-18-116). It should be noted that the new forms differ in the shape of the crown. In particular, the genotype 
'Slavka' has an orbicular shape; genotype Form 1-18-116 wide oval; 'Kyianochka' ovoid; Form 1-18-205 - inverted ovoid, 'Prydnistrianka' oblong.

According to the results of the research in 2017-2020, the beginning of vegetation of the T. glaberrima model plants (for example, of separate forms and seedling material) in the conditions of the Northern ForestSteppe falls in the third decade of March.

However, for some individual plants of that or another type the beginning of the bud burst was noted later(the first decade of April). We suppose that this is connected with the weather anomalies of the autumnwinter period in 2019-2020. We came to the conclusion that morphological inspections of buds, annual shoots of checker tree should be carried out on the sunny side in the middle part of the crown. This enables us to identify clearly the differences in the buds structure, whether there is gloss, pubescence, anthocyan colour, assess the shape and sizes as well as to detect the originality of the colour of the shoot bark, colour the presence of lenticels on the fruits, etc. This made it possible to differentiate the new forms in terms of both the vegetative bud apex shape and annual shoot colour. For instance, with 'Prydnistrianka', Form 1-18-116, and Form 118-205 the colour of the shoot of is light brown, 'Kyianochka' - brown, 'Slavka' - dark brown. The young checker tree shoot characteristics may be the intensity of its apex anthocyan colour, which for of 'Kyianochka', 'Prydnistrianka', Form 1-18-116, Form 1-18-205 is weak, and for the cultivar 'Slavka' is clearly expressed. But, we have not revealed the checker tree genotypes with the intensive (strong) anthocyanin colour or without it.

The plants of 'Slavka', 'Kyianochka', 'Prydnistrianka', Form 1-18116 have an orbicular vegetative bud apex; 'Form 1-18-205 - obtuse. The bud as a modified shoot is characterized by other signs as well, size, presence of pubescence, adhesive layer, the character of the location of the shoot. The size of the vegetative bud of the investigated forms varies greatly, from $8-15 \mathrm{~mm}$. This trait is genetically fixed, because it occurs annually and is characteristic of a concrete genotype, in particular, this bud of the Form 1-18-116 is small ( $8 \mathrm{~mm}$ ); of 'Kyianochka', 'Prydnistrianka', Form 1-18-116 average (9-14 mm); of 'Slavka' - large (15 mm), their position as concerns the shoot being either tightly ('Slavka', 'Prydnistrianka'), or slightly ('Kyianochka', Form 1-18-116), or clearly declined (Form 1-18-205).

The wild service tree plants acquire especial ornamentality during flowering, which lasts from the third decade of April to the first decade of May. The period of its beginning is determined when 5-10\% of the flowers are opened. Checker tree mountain ash produces bisexual flowers which are pollinated by a wide range of pollinators (honey bees, bumblebees and beetles). The flower colouration should be established on the first day of its opening. The flowers are located at the ends of the shoots, they are white, five-petalled, with strong or weak smell, collected in corymblike inflorescences. The inflorescence has 10-20 flowers on average. The flower diameter is up to $8-10 \mathrm{~mm}$, the shape of its petals is wide elliptical, orbicular or elongated. The petals' position is, as a rule, semi-straight or horizontal. Their location is free, tangential or overlapping. The flowers smell is strong. The corolla and perianth are simple.

Another checker tree plant polymorphism is the pistil type, which can be simple or complex (2, 3 stylodiyi or more). The results of the research have shown that the $T$. glaberrima flower is pistil apocarpous, has usually 2 , rarely 1,3 or 5 styloids (pistil columns). Ovary 2-3 nests lower, stigma being two-bladed. The morphological sign of the checker tree mountain ash flower was revealed, namely: the stigma position relative to the stamens. It can be lower ('Slavka', 'Prydnistrianka', Form 1-18-116), or at the same level ('Kyianochka', Form 1-18-205), or higher than the stamens. The shape of the stamens can be elliptical ('Slavka', 'Kyianochka', Form 1-18-116) or widely oval ('Prydnistrianka', Form 1-18-205). Their colouration varies from yellow ('Kyianochka', Form 1-18-116, Form 118-205) to dark yellow ('Slavka', 'Prydnistrianka'). The calyx with 5 sepals is, as a rule, low or average, while the scape is short 'Kyianochka' $(\leq 2 \mathrm{~cm})$, average - 'Slavka', 'Prydnistrianka', Form 1-18-116 (2-3 cm) or long $(\geq 3 \mathrm{~cm})$ - Form 1-18-205. The upper end of the scape and basis of the calyx are densely pubescent, and the calyx lobes are pubescent ('Prydnistrianka', 'Kyianochka') or not pubescent.

The T. glaberrima marker signs are form and leaf size. The morphological parameters of the checker tree leaves vary insignificantly depen- ding on the age of the studied plants. The juvenile plants as a rule are different from the mature ones as regards morphological parameters of the leaves. The first pair of the leaves, which appears in 8-9 days after the appearance of the cotyledons, differs from the adult ones. These leaves are simple, elliptical, wedge-shaped at the base, $2.5-4.0 \mathrm{~cm}$ long and 1.8 $2.5 \mathrm{~cm}$ wide, bare or sparsely pubescent. According to the research results the shape of the leaf blade of the mature plants may be ovate ('Slavka', 'Kyianochka', Form 1-18-205), obovate (Form 1-18-116), or widelyovate ('Prydnistrianka', Fig. 1). In accordance with the biometric parameters, the leaves of the mature plants are 5-13 cm long, and widely wedgeshaped at the base. The lobes are more or less acuminate, dark bright green on both sides, slightly pubescent beneath. The length of the petiole of the mature plants is $34-50 \mathrm{~mm}$, of the virgin ones $7-18 \mathrm{~mm}$.

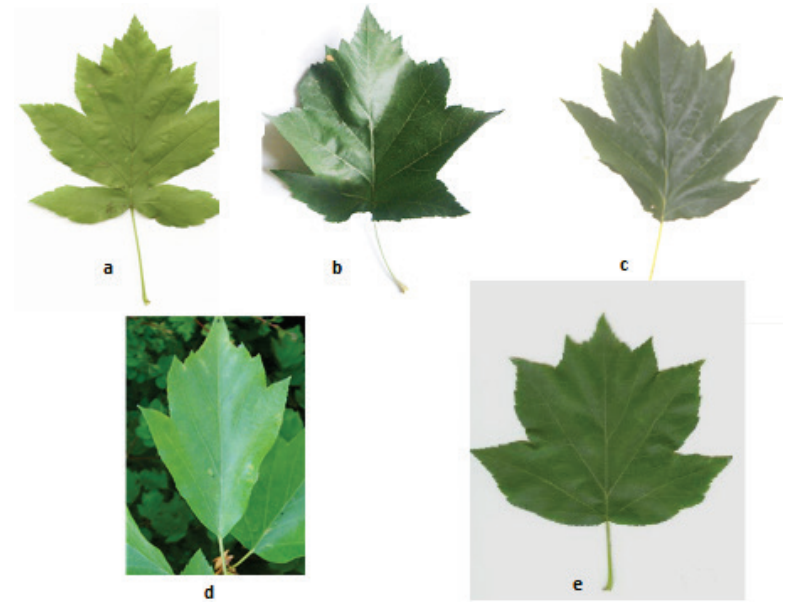

Fig. 1. The shape of the checker tree leaf blade of the mature plants: $a$ - 'Kyianochka' (ovate); $b$ - 'Slavka' (ovate); $c$-Form 1-18-205 (ovate); $d$-Form 1-18-116 (obovate); $e$ - 'Prydnistrianka' (widely-ovate)

One more morphological peculiarity is the degree of branching in conformity with which we differentiated the checker tree plants as moderate ('Slavka', Form 1-18-116) and strong ('Prydnistrianka', 'Kyianochka', Form 1-18-205). The degree of the plants' shoots makes the crown compact or on the contrary, rarefact, increasing thus the decorative value. We have noted signs of differences in the young shoots - colour (light brown - 'Prydnistrianka', Form 1-18-116, Form 1-18-205; brown - in 'Kyianochka'; dark brown - 'Slavka'), the presence of the anthocyan colouration of the young shoot top: weak ('Prydnistrianka', 'Kyianochka', Form 1-18-116, Form 1-18-205) or moderate ('Slavka').

The instant of the fruit ripening beginning is noted when $5-10 \%$ of fruits are ripe, and the time of their fruit maturation when 50 or more percent of all fruits are ripe. The fruit is considered ripe when it can be separated easily from the fruit stem. In the conditions of the Western, South-Western and Central Forest-Steppe the time of the T. glaberrima fruits biological ripeness is early (the third decade of July - the first decade of August - 'Kyianochka'), average (the second-third decades of August 'Prydnistrianka', 'Slavka', and Form 1-18-116 and average-late (the firstsecond decades of September - Form 1-18-205).

We detected varying parameters of the checker tree fruits - length, width, mass and so on. Thus, concerning the length the fruits of the studied forms can be divided into short $(<10 \mathrm{~mm})$, medium $(10-15 \mathrm{~mm})$, the majority of the explored biotypes: 'Kyianochka', Form 1-18-205) and long (> 15 mm - 'Slavka', 'Prydnistrianka', Form 1-18-116), as for width: narrow ( $>7 \mathrm{~mm}$ - Form 1-18-205), medium - 7-10 mm ('Kyianochka', 'Prydnistrianka'), wide ( $>10 \mathrm{~mm}$ - 'Slavka', Form 1-18-116). Their mass fluctuates from small - 0.5-1.2 g (Form 1-18-205), medium - 1.3-1.9 g ('Kyianochka', 'Prydnistrianka', Form 1-18-116), large - 2.0-2.5 g ('Slavka'). The fruit stem can be medium $-3.0-4.0 \mathrm{~cm}$ (Form 1-18-205) and long $>4.0 \mathrm{~cm}$ ('Slavka', 'Prydnistrianka', Form 1-18-116).

The main colouration of the fruit skin of the studied checker tree mountain ash biotypes is represented by a number of colours - from light brown ('Slavka', Form 1-18-116), brown ('Kyianochka'), to dark brown ('Prydnistrianka'). The texture of the fruit surface may be smooth or slightly rough ('Slavka', 'Kyianochka', 'Prydnistrianka'), or rough (Form 
1-18-205, Fig. 2). Interesting characteristies of the checker tree fruits are the presence of the lenticels - adaptation to ensure the gas exchange of the internal fruit tissues. As regards this sign, the fruits are subdivided into three groups: weakly dense ('Slavka', 'Kyianochka'), medium ('Prydnistrianka'), dense (Form 1-18-205, Form 1-18-116). The checker tree fruits are characterized by certain shedding patterns. It can be very weak under which individual fruits fall off, weak -5-10\% (Form 1-18-205, 'Slavka'), medium - 11-20\% ('Prydnistrianka'). It should be noted that the phenomenon of autochory of some genotypes ('Kiyanochka', Form 1-18-116) is strong (fruit shedding is $21-50 \%$ ) which contributes to the plant's adaptation to fruit and seed dispersal.

The seeds of the studied $T$. glaberrima biotypes vary slightly concerning colour in particular, from brown ('Slavka', Form 1-18-116, Form 118-205) to dark brown ('Kyianochka', 'Prydnistrianka'). The seeds of the checker tree are small. The average mass of 1000 seeds of most of the forms ('Slavka', 'Prydnistrianka', Form 1-18-116) is 17.2-20.4 g, (11.8 g), Form 1-18-205, and the cultivars 'Kyianochka' (the mass of 1000 seeds is $22.5 \mathrm{~g}$ have the smallest seeds). The significant positive correlation was revealed with the fruit mass $(\mathrm{r}=74.2 \%)$.

The biochemical analysis of the wild service tree fruits enabled us to detect the dry substances content at a level of $31.3-38.2 \%$ per wet mass, organic acids $-2.6-3.2 \%$ and total sugars $-7.3-8.5 \%$ during the berries' complete ripeness. The amount of such biologically active substances as polyphenolic compounds varies within 3124.6-3879.4 mg/kg, 'Kyianochka' having the lowest ascorbic acid content $(162 \mathrm{mg} / \mathrm{kg})$. The flavonoids' content varies within 3805.4-5176.2 $\mathrm{mg} / \mathrm{kg}$ during the period of the fruits complete ripeness of (Table 1).

\section{Table 1}

Biochemical composition of the fruits of some $T$. glaberrima forms (periods of the fruits' incompete ripeness, $\mathrm{x} \pm \mathrm{SD}, \mathrm{n}=12$ )

\begin{tabular}{|c|c|c|c|c|}
\hline \multirow[b]{2}{*}{$\begin{array}{l}\text { Fruits biochemical } \\
\text { composition indicators }\end{array}$} & \multicolumn{3}{|c|}{ Forms, cultivars } & \multirow[b]{2}{*}{ SE } \\
\hline & $\begin{array}{l}\text { 'Slavka' } \\
\text { (control) }\end{array}$ & 'Kyianochka' & F 1-18-116 & \\
\hline Solids, $\%$ wet mass & $31.3 \pm 1.2$ & $36.1 \pm 1.5^{* \prime \prime}$ & $38.2 \pm 1.2^{* \prime \prime}$ & 1.7 \\
\hline Sugar-acid index & $2.5 \pm 0.3$ & $3.3 \pm 0.2 * "$ & $2.3 \pm 0.2^{\prime \prime}$ & 0.8 \\
\hline $\begin{array}{l}\text { Polyphenolic compounds } \\
\text { (catechins), } \mathrm{mg} / \mathrm{kg}^{* *}\end{array}$ & $3650.1 \pm 62.5$ & $3124.6 \pm 47.0^{* \prime \prime}$ & $3879.4 \pm 53.6^{* \prime \prime}$ & 220.6 \\
\hline $\begin{array}{l}\text { Ascorbic acid content, } \\
\mathrm{mg} / \mathrm{kg}^{* *}\end{array}$ & $180.5 \pm 11.8$ & $162.0 \pm 15.3^{\prime \prime}$ & $205.7 \pm 8.0^{* \prime \prime}$ & 13.5 \\
\hline Flavonoids, mg/kg & $5010.2 \pm 21.8$ & $3805.4 \pm 19.3^{* \prime \prime}$ & $5176.2 \pm 21.0^{* \prime \prime}$ & 310.2 \\
\hline
\end{tabular}

Note: * - significance $\mathrm{P}<0.05$ as compared to the control (cultivar "Slavka'); " significance $\mathrm{P}<0.05$ as compared between variants; ** - fruits harvesting in the maturation phenophase; $\mathrm{SE}-$ standard error of the average.

\section{Discussion}

Cultivation of rare and endangered species and their subsequent repatriation to natural habitats is one of the main measures for conservation of biodiversity and the gene pool of plants of the world flora (Krynytskyi et al., 2017; Werres, 2018). This position is enshrined in many international documents, primarily in the Global Strategy for Plant Conservation and the European Strategy for Plant Conservation 2011-2020 (Hoebee et al., 2006). They clearly define the tasks of plant conservation ex situ 2020 in research institutions, protected areas, in ecosystem restoration programs (Paul et al., 2000; Zwierzyński \& Bednorz, 2012).

Both in Ukraine and abroad the main reason for population decline of T. glaberrima is the thoughtless exploitation of its natural specimens (Thomas, 2017), which led by the end of the XIX century and in the early XX century to the catastrophic reduction of its population to barely $1 \%$ of the total area of mixed forests (Demesure-Musch \& Oddou-Muratorio, 2004; Grynyk et al., 2019; Lefèvre et al., 2020). Checker tree free felling was suspended at the state level in the second half of the 1920's only through the awakening of ecological consciousness, and in due course, this species was listed in 'The Red Book' (Didukh, 2009) and state programs for its protection have been launched (Shpak et al., 2017). The addition of wild service tree to 'The Red Book' is only the initial stage of the program for its conservation as a rare and endangered species on the territory of Ukraine, aimed at increase in its population (Krynytskyi et al., 2017; Shpak, 2018;
Grynyk et al., 2019; Lefèvre et al., 2020). It should be noted that the checker tree is an aboriginal species and the extreme north-eastern limit of its distribution is: Zakarpattia, Peredkarpattia, Bukovyna, Podillia, some localities are in the mountainous Crimea (Kosets, 1941; Termena \& Budzhak, 1997; Mosyakin, 1999; Budzhak et al., 2000; Didukh, 2009). In addition, the species covers large areas in Western Europe, Turkey and the Caucasus, North Africa (Demesure-Musch \& Oddou-Muratorio, 2004; Zwierzyński \& Bednorz, 2012; Szymura et al., 2014; Thomas, 2017). In Europe this species is widespread in Great Britain, France, Italy, Germany, Romania, Serbia, as well as in other countries of the Balkan and Iberian Peninsulas, in some parts of Switzerland, the Caucasus (Fig. 3) (Demesure-Musch \& Oddou-Muratorio, 2004; de Rigo, et al., 2016; Thomas, 2017), where its average density ranges from 0.2 to 30 trees/ha (Moskalets et al., 2020).

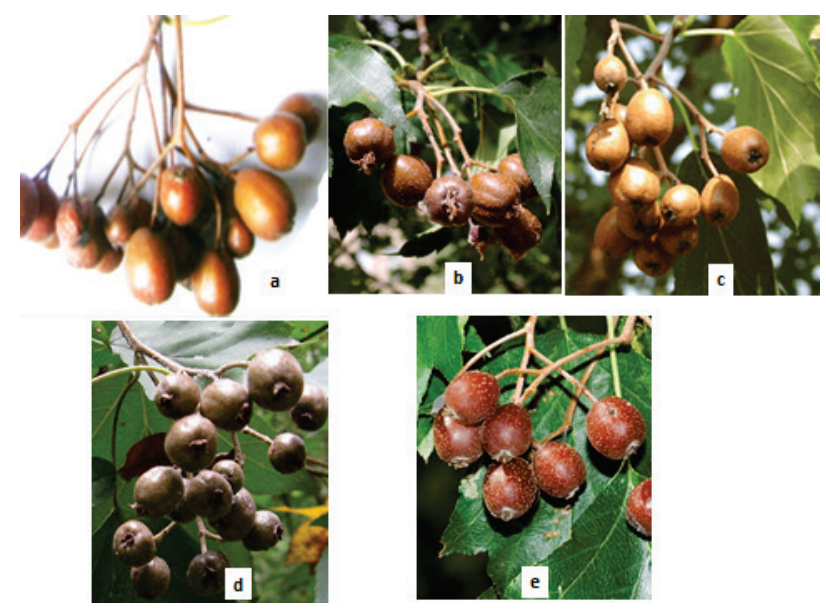

Fig. 2. The colouration of the checker tree fruit skin: $a$ - 'Slavka'; $b$ - 'Prydnistrianka'; $c$-Form 1-18-116; $d$-'Kyianochka'; $e$-Form 1-18-205

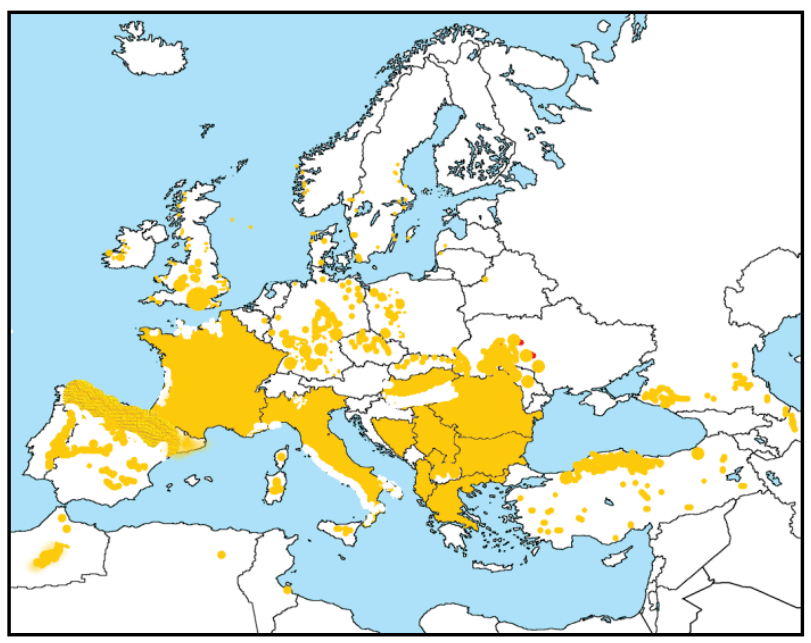

Fig. 3. The localization of checker tree in Europe, West Asia and North Africa (according to the data Demesure-Musch \& Oddou-Muratorio, 2004; de Rigo, et al., 2016; Thomas, 2017)

International experts (Zwierzyński \& Bednorz, 2012; Madera, 2013; Nemeth, 2015; Thomas, 2017) and national scientists (Kosets, 1941; Termena \& Budzhak, 1997; Shpak et al., 2017) have proved the priority of the study, preservation and restoration of populations of wild service tree given its vitality and environmental significance. In countries such as Germany, Serbia, Hungary, the Czech Republic, Austria, Poland and others, the checker tree was listed in the 'Red Book' and a start has been made to entry of selected genotypes to the Register of Plant Varieties (Ireland, Austria) (Grynyk et al., 2019; Moskalets et al., 2020). Areas under plantations of this species have increased in the last $10-15$ years in Germany, Austria, Poland to $1-10 \%$ of the initial area after its mass destruction. Monitoring studies are conducted on the state of checker tree 
populations and its distribution range is being studied with the aim of preventing the disappearance of this species from the green network of Ukraine (Pohrebniak, 1993; Shpak, 2019). In some European countries, in particular in Germany, laws have been passed to restore its plantations, which have allowed its current area to increase to more than $1 \%$ in the structure of all green areas (Paul et al., 2000; Amann, 2004; Pyttel et al., 2011). There is also evidence that it is becoming rarer in some areas such as eastern France, starting in 1988 (Allegrini et al., 1993), and central Europe (Drapier 1993a; Drapier 1993b). It has also been suggested that particularly tall trees of good form are being preferentially harvested and not replaced (Thomas, 2017), leading to the species becoming increasingly shrubby. Few European countries consider that wild service tree does not need nature conservation efforts (Lefevre et al., 2020), for example in Great Britain, where it has been classified as Least Concern using IUCN threat criteria (Moskalets et al., 2020). Yet, the species is considered endangered or under threat of disappearance, in particular in the north of its range (Northern Europe), central Germany and the Czech Republic (Bednorz, 2007; Bednorz \& Nowinska, 2018) and in Poland it has been protected by law since 1946 (Bednorz, 2007), as one of the rarest trees in the country (Szymura et al., 2014). State bodies are actively engaged in in situ and ex situ conservation (Zwierzynski \& Bednorz, 2012). The main threats to checker tree mountain ash are considered to be woodland clearance (reducing population size and increasing fragmentation), increased browsing, especially by deer.

As noted by many authors (Cheffings \& Farrell, 2005; Bednorz, 2007; Zwierzynski \& Bednorz, 2012; Cedro, 2016), the decline in coppicing with a concomitant rise in density of forests in uplands has led directly to large-scale population decline of the checker tree, increased fragmentation and reduced reproduction (Angelone et al., 2007; Thomas, 2017; Bednorz \& Nowinska, 2018) and it is expected that it will continue to decline without silvicultural intervention (Pyttel et al., 2011).

Careful study of distribution areas, living conditions, population structure of wild service tree is being conducted by scientists in different countries of Europe and the world. Thus, some scientists (Allegrini et al., 1993; Drapier, 1993) note the interaction of the species with biotic and abiotic environmental factors in France; others (Cheffings \& Farrell, 2005; Thomas, 2017) are studying this in the UK. Phenology, morphology, biochemical parameters of the fruits of the wild service tree are being actively studied by some researchers in Poland (Bednorz et al., 2007, 2012, 2018; Zwierzynski, 2012; Cedro, 2016; Jankowska-Wroblewska, 2016; Ulaszewski et al., 2017), and also in the Czech Republic (Madera et al., 2013); Serbia (Mrkonjić et al., 2017). Some scientists (Demesure-Musch \& Oddou-Muratorio, 2004) have conducted research to determine the features of morphology, physiology, and distribution range of he checker tree in Italy; in Iran (Shahraji et al., 2013; Espahbodi et al., 2017); in Hungary (Nemeth, 2015); Germany (Aas \& Kohles, 2011; Pyttel et al., 2013; Werres, 2018). In Ukraine - issues of study, conservation and protection T. glaberrima are engaging the attention of a number of researchers (Kosets, 1941; Pohrebniak, 1993; Termena \& Budzhak, 1997; Shpak et al., 2017, 2018, 2019), which has made it possible to determine the distribution range, ecological and biological features (Mosyakin, 1999; Shelyag-Sosonko et al., 2003) and somewhat popularize this species.

Today more and more attention is paid genetic research on this species to find out the center of origin, affinities of genotypes of different habitats, etc. Significant results have been obtained by European scientists (Jankowska-Wroblewska et al., 2016a, 2016b; Lefêvre et al., 2020) studying molecular genetic markers of individual populations of T. glaberrima (Angelone et al., 2007; Bailey et al., 2008; Espahbodi et al., 2017; Ulaszewski et al., 2017).

In order to preserve checker tree mountain ash, its widespread cultivation for its fruit and in ornamental horticulture is required, in particular, valuable forms in terms of vitality, decorativeness, etc. These genotypes must be included in the State Register of Plant Varieties of Ukraine, National Plant Genetic Bank, as well as to the Plant Variety Database (PLUTO), namely, to specific categories of varieties of decorative or fruit use, which will ensure their official registration and distribution both in the European Union, and in other countries. To do this, it is necessary to select valuable forms, create working collections, and form a genetic database. In this regard, in the Ukraine inventory, restoration, introduction and study of $T$. glaberrima by bioecological features, morphological peculiarities have a priority nature. Data and developments in the twentieth and early twenty-first century (Kosets, 1941; Termena \& Budzhak, 1997; Budzhak et al., 2000; Shpak, 2019) will serve as a necessary addition to new contemporary information.

Many researchers (Allegrini et al., 1993; Demesure-Musch \& Oddou-Muratorio, 2004; Mrkonjić et al., 2017) note that wild service tree has a wide range of dimensions - height ranges from 10-32 $\mathrm{m}$ (Bednorz et al., 2007; Madera et al., 2013) and trunk diameter 15-75 cm (Drapier, 1993; Pyttel, 2011) with dark grey bark, covered with cracks, strong wood (Nemeth, 2015; Cedro, 2016). According to data from some researchers (Mosyakin, 1999; Gordiyenko, 2007; Romanchuk, 2017; Shpak et al., $2017,2018,2019$ ) average annual growth of young individuals in height is $0.15-0.50 \mathrm{~m}$, life expectancy of checker tree is up to 300 years, and for some individuals -400 and more years. According to the results of our observations most individuals of reproductive age have an annual increase ('Slavka', Form 1-18-116) characterized as strong (more $40 \mathrm{~cm}$ ), however, the form 'Kyianochka') is weak (less than $30 \mathrm{~cm}$ ), and some ('Prydnistrianka', Form 1-18-205) - average (30-40 cm). The character and conditions of the locations of growth (relief, water, temperature regimes, plant population density, etc.) have a substantial influence on the manifestation of this feature.

Our research is confirmed by research by a number of authors (Termena \& Budzhak, 1997; Demesure-Musch \& Oddou-Muratorio, 2004; Bednorz et al., 2018), which show that the the phenomenon of heterostyly and cross-pollination is inherent in the checker tree mountain ash plant because the flowers have adaptations to entomophily (the presence of nectar secretion; pollen and pistils ripen at different times - manifestation of dichogamy (Bednorz et al., 2007, 2012, 2018; Madera et al., 2013; Nemeth, 2015); often unequal height of the stigma and stamens - the phenomenon of diversity - or heterostylia, which serves as protection from self-pollination, a kind of adaptation of flowers to pollination by insects (Madera et al., 2013; Nemeth, 2015).

Our research has revealed the diameter of the flowers 9-14 mm, small flowers are noted in 'Kyianochka' and the Form 1-18-205 (6$8 \mathrm{~mm}$ ). A number of authors (Bednorz \& Urbaniak, 2005; Thomas, 2017; Werres, 2018) have detected both large $(10-15 \mathrm{~mm})$, and small (7$10 \mathrm{~mm}$ ) flowers. The flowers are $10-15 \mathrm{~mm}$ diameter, with five white patent petals and 18-24 creamy-white stamens; they are produced in corymbs 5-12 cm diameter. If the calyx in the wild service tree is exclusively 5-petalled, the intensity of hairs is a marker sign. It may be more pubescent ('Kyianochka', 'Prydnistrianka', Form 1-18-116) or less pubescent (all other studied forms). According to European researchers (Nemeth, 2015; Sennikov \& Kurtto, 2017; Thomas, 2017) in the conditions of North-Western Europe the flowering period falls at the end of May, however, according to our observations, in the conditions of the Western and Central Forest-Steppe of Ukraine, the time of the beginning of flowering is noted a little earlier-I-II decades of May.

Leaves in T. glaberrima are alternate, finger-blade (resembling a hand), at the ends of the blades are sharpened. According to the shape of the leaf blade, we found three varieties: obovate, ovate, widely-ovate. Some authors (Drapier, 1993a; Pyttel et al., 2013; Thomas, 2017; Werres, 2018) also allocate wide-triangular, heart-ovate and wedge.

Young leaves are mostly a little hairy from the top side, over time they become leathery, dark green, shiny, not hairy, on the underside they are of a pale green colour with pubescence of the blade or veins. According to Polish scientists (Bednorz \& Urbaniak, 2005; Bednorz et al., 2012; Bednorz \& Nowinska, 2018), who conducted a study of 15 morphological signs of checker tree mountain ash natural populations of Poland, leaves were found to be ovate, 4-11 cm wide and $15-18 \mathrm{~cm}$ in length, slightly cordate (heart-shaped, stem in cleft) or cuneate at base, with 3-5 acute lobes. Sometimes the lowermost pair of lobes were very acute and deeply dissected, leaves finely acutely dendate at margin, young pubescent. If the above authors classify the leaves of $T$. glaberrima into 4 types and 19 varieties, Iranian researchers (Shahraji et al., 2013) allocate six types of leaves among populations of $T$. glaberrima: oval, sharp tipped, fine toothed; lobed, wedge; lobed, heart shape, sharp tipped; lobed, semi circle, sharp tipped; narrow, sharp tipped; lobed, semi elliptical, sharp tipped. Polymorphism is the existence of a number of different forms 
within a species, whether caused by genetic or environmental factors. Also some authors (Thomas, 2017; Bednorz \& Nowinska, 2018) observed significant differences for checker tree mountain ash leaves within a tree, although other researchers (Bednorz \& Urbaniak, 2005; Werres, 2018) observed a moderate level of variation in checker tree leaves. In the western part of Guilan province (Iran), high polymorphism in the form of T. glaberrima leaves was discovered by other researchers (Shahraji et al., 2013). They observed fifteen common shapes of leaves in four studied areas. Also most collected leaves were seven lobed, differences between petiole lengths were weakly significant within $3.3-3.7 \mathrm{~cm}$.

Wild service tree fruits are edible, have a sour-sweet taste similar to the taste of pears. The weight of the fruit of a 20 year old tree of the 'Slavka' form, found in Khmelnytskyi region was 2.0-2.5 g, although the weight of the fruit, collected in other areas of Western and Central Polissia (Vinnytsia region, Kyiv region) was much lower (0.9-1.4 g). According to studies by other authors (Termena \& Budzhak, 1997; Shpak, 2018) fruit weight in oak-ash-checker tree plantations of Northern Bukovyna and 'Karmeliukove Podillia' National Nature Park (Central Ukraine) was low (0.98 g), abundance of fruiting was low (less than $3 \mathrm{~kg}$ from a 40year-old tree); in oak-hornbeam plantations, the average weight of the fruit was $1.33 \mathrm{~g}$, abundance was average, but in checker trees growing on the edge of the forest - abundance was high (6-8 kg of 30-40-year-old trees). However, one author (Shpak, 2018) found 30-year-old checkertree trees with large fruits, with an average weight of $2.58 \mathrm{~g}$ and a high abundance $(12.5 \mathrm{~kg})$ of fruit.

According to biometric studies, the length of the fruit varies within $10-15 \mathrm{~mm}$ (most of the researched forms), However, some fruits are large ('Slavka', 'Prydnistrianka', Form 1-18-116). The width of the fruit varies between 7-10 mm, although there are some forms among them ('Slavka', Form 1-18-116) more than $10 \mathrm{~mm}$ in width. The average size of the wild service tree fruits in the UK (Thomas, 2017), Germany (Aas \& Kohles, 2011; Pyttel, 2011) and other countries varies between $12-15 \mathrm{~mm}$ in length and 8-12 $\mathrm{mm}$ in diameter, which is consistent with our data. According to a number of authors (Szymura, 2014; Bednorz et al., 2017, 2018; Werres, 2018) the number and dimensions of fruits and seeds are important biological properties which, among other things, influence the ability for generative propagation of the wild service tree.

Results of data analysis showed that in Iran (Shahraji et al., 2013) checker tree fruits from low elevations were bigger than the fruits from higher elevations. According to the shape of the fruit we found an elliptical shape, however, rounded fruits are less common (Form 1-18-205). The result of analysis of fruit shape by Shahraji et al. (2013) in the western part of Guilan province (Iran) indicated two shapes such as apple shapes (spheroid type) and pear shapes (ellipsoid type).

Seeds isolated from the fruits of wild service tree which germinate in areas of Poland, Great Britain, France, the Czech Republic (Drapier, 1993a; Bednorz, 2007; Madera, 2013), Italy, Spain, Germany (DemesureMusch \& Oddou-Muratorio, 2004; Aas \& Kohles, 2011; Coello et al., 2013) were elongated, pointed, from $0.6-0.8 \mathrm{~cm}$ in length, $-0.3-0.5 \mathrm{~cm}$ in width and of $0.2-0.3 \mathrm{~cm}$ thick, sometimes flat. These authors found that depending on the variety of shapes wild service tree seeds can range in colour from light brown to dark brown or even black. Thus, according to Thomas (2017) the seed itself is very variable in size and shape, even within the same corymb. More commonly obovate to round, and sometimes obovate or elliptical shaped, they measure an average of $\sim 14 \mathrm{~mm}$ long and $\sim 11 \mathrm{~mm}$ wide but can measure anywhere between $8.2-19.6 \mathrm{~mm}$ long and 8.2-15.5 mm wide (Bednorz, 2007). The trees from Medvednica in the Republic of Croatia (Orsanic et al., 2009) had the largest fruit length/fruit width index (1.31), followed by Psunj (1.20) and Ju'ni Dilj (1.18). The index helps the authors notice that the fruits from Medvednica were more oblong-shaped compared to the other two sites. The fruit length/fruit width index showed a significant difference between the sites $(\mathrm{F}=8.29, \mathrm{P}=0.002)$. These significant differences in fruit weight and trunk diameter helped the authors conclude that checker trees with larger diameters give larger fruits. Espahbodi et al. (2002, 2007, 2017) conducting research in Iran, found that average weight of fruits (4 000 specimens) was $1.24 \mathrm{~g}$ (ranging 0.89-1.71), which is consistent with the data which we received in Vinnytsia region. Bednorz et al. (2007, 2017, 2018) reported that the seeds range in shape from mostly obovate $( \pm 77 \%)$, to elliptical $( \pm 12 \%)$, to oblanceolate $( \pm 6 \%)$, to wide obovate $( \pm 4 \%)$ and sometimes are oblong or roundish $( \pm 1 \%)$; their average size is $\sim 6.2 \mathrm{~mm}$ long and $\sim 3.2 \mathrm{~mm}$ wide, but they range $3.2-8.1 \mathrm{~mm}$ in length and 1.7$5.7 \mathrm{~mm}$ in width.

According to our analysis, the weight of 1000 pcs. seeds checker tree mountain ash natural and anthropogenic plantations ranges $15.2-25.7 \mathrm{~g}$, their number in the fruit - 1-2, at least - not one. Our data are not confirmed by the research results of Orsanic et al. (2009), who found that in the conditions of the Republic of Croatia in a fruit of the majority of populations there were two seeds, rarely 1,4 , very rarely 6 or more. Research conducted in Croatia (Orsanic et al., 2009), as well as in Poland (Bednorz et al., 2017, 2018) demonstrated that three morphological properties (number of lenticels on fruit, number of seeds per fruit and seed length) are the main factors contributing to the differences between populations of the wild service tree. Pemature fruits appear in August-September. The fruit ripening period in plants of the studied areas fluctuates slightly. Basically it takes place in the II decade of August - I-II decades of September. Fruit ripening in Poland, Germany, Great Britain begins in mid-August (Aas \& Kohles, 2011; Werres, 2018) and lasts throughout September (Hoebee et al., 2006; Thomas, 2017).

T. glaberrima as a promising multipurpose species needs more detailed study. Therefore, based on our own research and research by national and foreign authors, we have compiled a system of sign indicators, which can be the first step in the use of criteria enabling characterization and assessment of variability of $T$. glaberrima, and facilitate identification and exchange of germplasm. Its delicious fruits are used for making wine, jam and other food products due to the high content of vitamins (Aas \& Kohles, 2011; Gaivelyte et al., 2013; Rich, et al., 2014), and also as a drug in national medicine (Kosets, 1941; Gordiyenko, 2007). Wild service tree may take a prominent place in fruit horticulture. To date, the biochemical composition of checker tree mountain ash fruits has been studied in insufficient detail, but there are reports about its healing properties (Gostyshchiev et al., 2010; Mrkonjić et al., 2017). There is growing number of reports about the chemical composition and pharmacological properties of fruits and leaves of different species of Sorbus (Gaivelyte et al., 2013; Kushnerova et al., 2014; Hasbal et al., 2015). It has been demonstrated that the fruits of Sorbus aucuparia L., Aronia melanocarpa (Michx.) Elliott, and Sorbus torminalis L. (T. glaberrima) contain flavonoids; steroids: cholesterol, campesterol, stigmasterol, sitosterol; higher fatty acids: myristic, palmitic, palmitoleic, stearic, oleic, linoleic, linolenic, leaves flavonoids: astragalin, vitexin, quercetin, quercetin-3- $\beta$-sophoroside, kaempferol-3-in-3- $\beta$ luteolin-7-glucoside, luteolin-4'-O-glucoside, luteolin-7-O-diglucoside, luteolin-7-oramnosylglucoside, hyperoside, isoquercitrin (Budantsev, 2009; Gaivelyte et al., 2013); phenolic carboxylic acids: chlorogenic, n-coumaric, caffeic; branches and leaves - triterpenoid ursolic acid (Olszewska \& Michel, 2009; Baltacioglu et al., 2011; Olszewska, 2011). It has also been shown that checker tree extracts have antioxidant activity (Mikulic-Petkovsek, 2017; Mrkonjić et al., 2017), exhibit antiinflammatory, hypoglycemic action, which is important in the prevention of atherosclerosis (Olszewska, 2011; Kushnerova et al., 2014; Hasbal et al., 2017). Of the flavonoids, flavonols predominate - kaempferol and quercetin derivatives, from flavones dominate - derivatives of apigenin and luteolin; and flavonoid C-glycoside vitexin (apigenin-8-C-glucoside) (Budantsev, 2009; Hasbal et al., 2015).

Water and solids are the main part of the chemical composition of fruits of T. glaberrima. The solids content in the fruits of the genus Sorbus is on average 21.5-32.0\% (Kushnerova et al., 2014; Mikulic-Petkovsek, 2017 ) and in the fruits of wild service tree their content $-31-38 \%$ of the wet weight. These substances determine mainly the mechanical strength of tissue, their consistency, colour. Dry soluble substances (SRP) are contained in cell juice. Their total content in the fruits can vary from 28.630.2\% (Gaivelyte et al., 2013; Kushnerova et al., 2014; Hasbal et al., 2015; Mrkonjic et al., 2017), and according to our research $-34.0-37.4 \%$ by wet weight (Grynyk et al., 2019). Their main part is represented by carbohydrates (the vast majority - sugars), nitrogenous and tannins, acids, etc. Wild service tree fruits contain vitamin $\mathrm{C}$ - ascorbic acid, which is important in human nutrition and participates in various types of metabolism, promotes the assimilation of proteins by the body, iron, a number of vitamins, regulates cholesterol metabolism (Kushnerova et al., 2014; 
Hasbal et al., 2015; Mrkonjic et al., 2016). This maintains the strength of the walls of blood vessels (due to participation in collagen synthesis intermediate connective tissue), increases the body's resistance to external influences and infections (Olszewska \& Michel, 2009; Moskalets et al., 2019). As a result of our research, it was found that during the maturation of the fruits of wild service tree the highest content of vitamin $\mathrm{C}$ is found in F-1-18-116 and variety 'Slavka' (116-205 mg/kg, respectively). However, in the phenophase of full maturity, the content of vitamin $C$ in the fruits of checker tree decreases by $12-27 \%$. Fruits of other members of the genus Sorbus, in particular S. aucuparia have a 3-6 times higher content of ascorbic acid than the fruits of T. glaberrima (Gaivelyte et al., 2013; Kushnerova et al., 2014; Hasbal et al., 2015; Mrkonjic et al., 2017).

One of the indicators which determine the taste of the fruit is the content of organic acids and total sugars. Our research found that the content of titrated organic acids ranges $2.3-3.3 \%$. The content of total sugars is much higher, in particular 2.3-3.3 times, which is reflected in the sugaracid index (SAI). It has been shown that extracts fruits of $T$. glaberrima are used both in traditional medicine as a antidiabetic, antiinflammatory, diuretic, vasoprotective and in foods (Hasbal et al., 2015). The connection between the content of phenols and flavonoids of fruits and antidiabetic activity is shown. T. glaberrima extracts exhibited strong $\alpha$-glucosidase inhibitory activity, more effective than that of standard drug acarbose. The abovementioned authors suggest that antidiabetic effects of the fruits may be due to phenolic compounds present therein.

Chemical analysis shows that fruits of checker tree mountain ash and some of its relatives meet the criteria for being named a 'functional food' (Olszewska, 2011; Mrkonjic et al., 2017) because they have high levels and types of endogenous phenolics and other compounds that are known to promote the prevention and treatment of infections and diseases (Raudone et al., 2014; Mikulic-Petkovsek et al., 2017). Thus, it can be stated that the fruit of the wild service tree is a valuable raw material for health food and the pharmaceutical industry. Due to global climate change more and more attention is paid to the search for highly drought-resistant ornamental species more (Coello et al., 2013; Krynytskyi et al., 2017; Moskalets et al., 2019). T. glaberrima is highly tolerant of droughts that last a few months, fully meets these requirements, which is important in phytodesign and the creation of long-lasting landscape compositions (Paul et al., 2000; Madera et al., 2013; Thomas, 2017). Wild service tree possessing a number of important biological qualities (Pohrebniak, 1993; Amann, 2004; Cedro, 2016; Moskalets et al., 2019; Lefèvre et al., 2020) is one of the best companions for Quercus robur L. and Q. petraea (Matt.) Liebl., Fagus sylvatica L., Carpinus betulus L. and other forest-forming species (Pyttel et al., 2011; Romanchuk, 2017; Shpak, 2018) due to which it can be widely used in forest crops, the field protective forestry and green building.

$T$. glaberrima conservation should be practised not only at the local level (several hectares) but at the landscape level or even on the regional scale. For now, it is not possible to indicate a critical population size below which the populations would be threatened. Scientists and practitioners need to make an effort to ensure the conservation of the species on the local level, in favour of each single tree (genotype).

\section{Conclusions}

As a result of the expeditionary inspections 14 checker tree mountain ash populations and 43 genotypes in the territory of Western, SouthWestern and Central Forest-Steppe were studied. 5 forms were selected with high vigour (the annual increment was more than 30-40 cm), large fruit mass (1.7-2.4 g) and which are valuable in terms of environmental plasticity, ornamentality and as components of oak-beech, oak-hornbeam associations, green corridors of the ecological network, including parks, squares, alleys, other nature protection areas, as well as orchards. The indicators were singled ou, which are basic when selecting valuable morphobiotypes in natural and anthropic ecotopes. It is important to promote the propagation of the species by means of its widespread introduction into fruit cultivation and ornamental horticulture, which will contribute to the fulfilment of their intended purpose and preservation of the species, which is listed in Red Book as disappearing from the gene pool of plants in Ukraine. The biochemical analysis has shown that $T$. glaberrima fruits are valuable raw material for consumption thanks to the high content of the biologically active substances: polyphenolic compounds (3124.6$3879.4 \mathrm{mg} / \mathrm{kg}$ ), flavonoids (3805-5175 mg/kg), vitamin C $(162-$ $205 \mathrm{mg} / \mathrm{kg}$ ). Widespread use of the wild service tree by its introduction to the new growing conditions in fruit and ornamental horticulture and forestry will make it possible to supply consumers and the pharmaceutical market with organic raw material for the manufacturing of food and medicinal products.

The authors are very grateful to V. V. Frantsishko and V. M. Batochenko for the assistance in conducting the route inspections and technical aid during the fieldwork, creating the research site and acquisition of field data.

\section{References}

Aas, G., \& Kohles, M. (2011). Verbreitung, Haufigkeit und Verjungung von Sorbus cordigastensis (Kordigast-Mehlbeere) in der nordlichen Frankenalb. Tuexenia, $31,59-71$

Allegrini, C., Giard, D., \& Mariel, M. (1993). Perpetuer et ameliorer la ressource locale en alisiers: Un projet Haut-Saonois. Revue Forestiere Francaise, 45, 383-387.

Amann, G. (2004). Baume und Straucher des Waldes. Neumann-Neudamm Verlag, Melsungen.

Andrianova, T. V. (2001). Phyllotrophic mitosporic fungi of "Cape Mart'ian" Nature Reserve (Ukraine, Crimea). Mikologiya i Fitopatologiya, 35,1-10.

Angelone, S., Hilfiker, K., Holderegger, R., Bergamini, A., \& Hoebee, S. E. (2007). Regional population dynamics define the local genetic structure in Sorbus torminalis. Molecular Ecology, 16, 1291-1301.

Austerlitz, F., Dick, C. W., Dutech, C., Klein, E. K., Oddou-Muratorio, S., Smouse, P. E., \& Sork, V. L. (2004). Using genetic markers to estimate the pollen dispersal curve. Molecular Ecology, 13, 937-954.

Badurowa, M., \& Badura, L. (1968). A comparative study on the occurrence of microscopic fungi on leaves and needles from different species of trees growing within the Reserve “Kamien Slazski”. Ekologia Polska-Seria A, 16,253-260.

Bailey, J. P., Kay, Q. O. N., McAllister, H., \& Rich, T. C. G. (2008). Chromosome numbers in Sorbus L. (Rosaceae) in the British Isles. Watsonia, 27, 69-72.

Baker, J. G. (1885). A Flora of the English Lake District. George Bell \& Sons, London.

Balandier, P., Frochot, H., \& Sourisseau, A. (2009). Improvement of direct tree seeding with cover crops in afforestation: Microclimate and resource availability induced by vegetation composition. Forest Ecology and Management, 257, 1716-1724.

Baltacioglu, C., Velioglu, S., \& Karacabey, E. (2011). Changes in total phenolic and flavonoid contents of rowanberry fruit during posthatvest storage. Journal of Food Quality, 34, 278-283.

Bamberger, U. (1990). Ergebnisse des Elsbeer-Herkunftsversuchs im Kaiserstuhl. Allgemeine Forst Zeitschrift, 45, 817-818.

Barengo, N., Rudow, A., \& Schwab, P. (2001). Forderung seltener Baumarten auf der Schweizer Alpennordseite. Swiss Agency for Environment, Forests and Landscape and Eidgenossische Technische Hochschule, Zurich, Bern, Switzerland.

Barnola, P., Durand, P., \& Parmentier, C. (1993). Recherches preliminaires sur la croissance et la morphoge nese de l'alisier torminal. Revue Forestiere Francaise, 45, 261-278.

Battut, A., Grenier, E., \& de March, G. (1993). Micropropagation de Sorbus torminalis L. Revue Forestiere Francaise, 45, 284-288.

Bean, W. J. (1980). Trees and shrubs hardy in the British Isles. 8th edn. Murray, London.

Bednorz, L. (2006). Morphological variability of leaves of Sorbus torminalis (L.) Cratz in Poland. Acta Societatis Botanicorum Poloniae, 75, 233-243.

Bednorz, L. (2007). Morphological variability of fruits and seeds of Sorbus torminalis in Poland. Dendrobiology, 57, 3-14.

Bednorz, L. (2007b). The wild service tree Sorbus torminalis (L.) Crantz in plant communities of Poland. Dendrobiology, 57, 49-54.

Bednorz, L. (2007c). Conservation of genetic resources of Sorbus torminalis in Poland. Dendrobiologia, 58, 3-7.

Bednorz, L. (2009). Jak chronic jarzaz b brekiniez (Sorbus torminalis) w polskich lasach? [How to protect wild service tree (Sorbus torminalis) in Polish forests?]. Sylwan, 153, 354-360.

Bednorz, L., \& Krzakowa, M. (2002). Phosphoglucose isomerase (PGI) polymorphism in Sorbus torminalis (L.) Crantz. Acta Societatis Botanicorum Poloniae, $71,121-124$.

Bednorz, L., \& Nowinska, R. (2018). Analysis of growth of recruits of natural regeneration of Sorbus torminalis (L.) Crantz - a rare European forest tree species. iForest, 11, 72-78. 
Bednorz, L., \& Urbaniak, A. (2005). Phenology of the wild service tree (Sorbus torminalis (L.) Crantz) in Poznan and Wielkopolski National Park. Dendrobiology, 53, 3-10.

Bednorz, L., Kazmierczak, K., \& Kaczmarek, L. (2012). Analyses of spatial structure and selected measures of growth of Sorbus torminalis in forest district Jamy (Northern Poland). Dendrobiology, 67, 59-65.

Bednorz, L., Maciejewska-Rutkowska, I., Wronska-Pilarek, D., \& Fujiki, T. (2005) Pollen morphology of the Polish species of the genus Sorbus L. Acta Societatis Botanicorum Poloniae, 74, 315-322.

Bednorz, L., Myczko, L., \& Kosinski, P. (2004). Isozyme polymorphism and genetic structure of the population of Sorbus torminalis (L.) Crantz from the Bytyn Forest (Poland). Journal of Applied Genetics, 45, 321-324.

Bednorz, L., Myczko, L., \& Kosinski, P. (2006). Genetic variability and structure of the wild service tree (Sorbus torminalis (L.) Crantz) in Poland. Silvae Genetica, $55,197-202$

Bednorz, L., Walkowiak, R., Maciejewska-Rutkowska, I., \& Molinski, K. (2006) Seed variability of the Polish species of the genus Sorbus (Rosaceae). Dendrobiology, 55, 3-9.

Beydemann, I. N. (1974). Metodika izuchieniya fenologii rastieniy i rastitielnykh soobschiestv [Methods of studying the phenology of plants and plant communities]. Nauka, Novosibirsk (in Russian).

Budantsev, A. L. (Ed.). (2009). Rastitielnyie riesursy Rossii. Dikorastushchihe tsvietkovyie rasteniia, ih komponientnyi sostav i biologichieskaia aktivnost. Siemieystva Actinidiaceae - Malvaceae, Euphorbiaceae - Haloragaceae [Plant resources of Russia. Wild flowering plants, their component composition and biological activity. Family Actinidiaceae - Malvaceae, Euphorbiaceae - Haloragaceae]. Kolos, Moscow (in Russian).

Budzhak, V. V., Chornei, I. I., Havryliuk, V. O., \& Turlai, O. L. (2000). Heobotayichna kharakterystyka roslynnykh uhrupovan Pivnichnoi Bukovyny ta Pivnichnoi Bessarabii za uchastiu Sorbus torminalis (L.) Crantz. [Northem Bukovyna and Northem Bessarabia geobotanical characteristics plant groups with Sorbus torminalis (L.) Crantz.]. Ruta, Chernivtsi (in Ukrainian).

Cedro, A. (2016). Dendrochronologiczna analiza jarzebu brekinii (Sorbus torminalis L.) w Polsce [Dendrochronological analysis of the wild service tree (Sorbus torminalis L.) in Poland]. Zapol Sobczyk Spólka Jawna, Szczecin (in Polish).

Coello, J., Becquey, J., Ortisset, J. P., Gonin, P., Baiges, T., \& Pique, M. (2013) Ecology and silviculture of the main valuable broadleaved species in the Pyrenean area and neighbouring regions. Ministry of Agriculture, Livestock, Fisheries, Food and Natural Environment, Government of Catalonia and Catalan Forest Ownership Centre, Catalonia

Coello, J., Becquey, J., Ortisset, J. P., Gonin, P., Baiges, T., \& Pique, M. (2013) Ecology and silviculture of the main valuable broadleaved species in the pyrenean area and neighbouring regions. Government of Catalonia and Catalan Forest Ownership Centre, Santa Perpètua de Mogoda.

Coetzee, B. W. T. (2017). Evaluating the ecological performance of protected areas. Biodiversity and Conservation, 26(1), 231-236.

de Rigo, D., Caudullo, G., Houston Durrant, T., \& San-Miguel-Ayanz, J. (2016). The European atlas of forest tree species: Modelling, data and information on forest tree species. Publication Office of the European Union, Luxembourg.

Demesure, B., Guerroué, G., Lucchi, D., Prat, D., \& Petit, R. (2000). Genetic variability of a scattered temperate forest tree: Sorbus torminalis L. (Crantz). Annals of Forest Science, 57, 63-71.

Demesure-Musch, B., \& Oddou-Muratorio, S. (2004). Euforgen technical guidelines for genetic conservation and use for wild service tree (Sorbus torminalis). International Plant Genetic Resources, Rome.

Didukh, Y. P. (Ed.). (2009). Chervona knyha Ukrainy. Roslynnyi svit [Red Data Book of Ukraine. Plant kingdom]. Globalconsulting, Kyiv (in Ukrainian).

Drapier, N. (1993a). Connaissance du genre Sorbus. Les Sorbus en France: Caracteres botaniques et generalites. Revue Forestiere Francaise, 45(3), 207-215.

Drapier, N. (1993b). Ecologie del'alisier torminal, Sorbus torminalis (L.) Crantz. Revue Forestiere Francaise, 45(3), 229-243.

Espahbodi, K., Mirzaei-Nadoushan, H., Emadian, S. F. A., Sabbagh, S., \& Ghasemi, S. (2002). The effect of sowing depth and soil protection for seed germination of service tree (Sorbus torminalis) in a mountainous nursery. Iranian Journal of Natural Resources, 55(1), 47-55.

Espahbodi, K., Mirzaie-Nodoushan, H., Tabari, M., Akbarinia, M., Jalali, S., \& Hosseini, S. (2007). Seed source effects on seed emergence, seedling survival and growth on wild service (Sorbus torminalis) seedlings. International Joumal of Agriculture and Biology, 9, 426-430.

Espahbodi, K., Mirzaie-Nodoushannodoushan, H., Tabari, M., Akbarinia, M., Dehghan-Shuraki, Y., \& Jalali, S. G. (2017). Genetic variation in early growth characteristics of two populations of wild service tree (Sorbus torminalis (L.) Crantz) and their interrelationship. Silvae Genetica, 57, 1-6.

Gaivelyte, K., Jakstas, V., Razukas, A., \& Janulis, V. (2014). Variation of quantitative composition of phenolic compounds in rowan (Sorbus aucuparia L.) leaves during the growth season. Natural Product Communications, 28(8), 1018-1020.

Gordiyenko, M. I. (2007). Lisovi kultury rivnynnoi chastyny Ukrainy [Forest crops of the lowland part of Ukraine]. Naukova Dumka, Kyiv (in Ukrainian).
Grynyk, I., Moskalets, T., Frantsishko, V. S, Moskalets, V., Chmyr, S., Lyaskovsky, A., Frantsishko, V., Frantsishko, V. V., \& Matlai, I. (2019). Bereka (Sorbus torminalis (L.) crantz): Novi selektsiyni formy ta perspektyvy ih vykorystannia v sadivnytstvi [Checkertree mountainash (Sorbus torminalis (L.) crantz): New breeding forms and promises of their use in horticulture]. Horticulture, 74, 4565 (in Ukrainian)

Hasbal, G., Yilmaz-Ozden, T., \& Can, A. (2015). Antioxidant and antiacetylcholinesterase activities of Sorbus torminalis (L.) Crantz (wild service tree) fruits. Journal of Food and Drug Analysis, 23(1), 57-62.

Hoebee, S., Menn, C., Rotach, P., Finkeldey, R., \& Holderegger, R. (2006). Spatia genetic structure of Sorbus torminalis: The extent of clonal reproduction in natural stands of a rare tree species with a scattered distribution. Forest Ecology and Management, 226, 1-8.

Jankowska-Wroblewska, S., Meyza, K., Sztupecka, E., Kubera, L., \& Burczyk, J. (2016a). Clonal structure and high genetic diversity at peripheral populations of Sorbus torminalis (L.) Crantz. iForest, 9, 892-900.

Jankowska-Wroblewska, S., Warmbier, J., \& Burczyk, J. (2016b). Spatial genetic structure within populations of Sorbus torminalis (L.) Crantz: Comparative analysis of the self-incompatibility locus and nuclear microsatellites. Acta Biologica Cracoviensia, Botanica, 58(1), 7-17.

Krynytskyi, H. T., Hayda, Y. I., Yatsyk, R. M., Parpan, V. I., \& Los, S. A. (2017). Concept for the conservation and sustainable use of forest genetic resources in Ukraine. Scientific Bulletin of National Forestry University of Ukraine, 27(8), $37-44$.

Kushnerova, N. F., Momot, T. V., Fomenko, S. Y., \& Sprygin, V. G. (2014). Profilaktika stressovyikh narusheniy uglevodnogo i lipidno go obmiena piechieni ekstraktom iz otzhima plodov riabiny [Prevention of stress disorders of carbohydrate and lipid metabolism of the liver extract from the extraction of rowan berries]. Health, Medical Ecology, Science, 56, 36-38 (in Russian).

Kosets, M. I. (1941). Systematyka, heohrafichne poshyrennia i istoriia Sorbus torminalis (L.) Crantz na foni zahalnogo rozvytku rodu Sorbus L. [Systematics, geographical distribution and history Sorbus torminalis (L.) Crantz against the background of the general development of the genus Sorbus L.]. Botanical Journal of the USSR Academy of Sciences, 2(1), 43-50 (in Ukrainian).

Lefêvre, F., Alia, R., Bakkebo Fjellstad, K., Graudal, L., Oggioni, S., Rusanen, M., Vendramin, G., \& Bozzano, M. (2020). Dynamic conservation and utilization of forest tree genetic resources: Indicators for in situ and ex situ genetic conservation and forest reproductive material. European Forest Institute, Barcelona

Madera, P., Ticha, S., \& Repka, R. (2013). Distribution and ecological requirements of Sorbus torminalis (L.) Crantz in the Czech Republic. Dendrobiology, 69, 59-68.

Mikulic-Petkovsek, M., Krška, B., Kiprovski, B., \& Veberic, R. (2017). Bioactive components and antioxidant capacity of fruits from nine Sorbus genotypes. Journal of Food Science, 82(3), 647-658.

Mikulic-Petkovsek, M. Ivancic, A, Schmitzera, V., Veberica, R \& Stampara, F. (2016). Comparison of major taste compounds and antioxidative properties of fruits and flowers of different Sambucus species and interspecific hybrids. Food Chemistry, 200, 134-140.

Moskalets, T. Z., \& Rybalchenko, V. K. (2016). Kontseptualna model keruvannia zhyttievym stanom roslynnykh ekomorf za kryteriiamy mekhanizmiv adaptyvnosti [Conceptual model of management the vital state plant ecomorphs by the criteria of adaptation mechanisms]. Visnyk of Dnipropetrovsk University, Biology, Ecology, 4(1), 211-221 (in Ukrainian).

Moskalets, T. Z., Moskalets, V. V., Vovkohon, A. H., Shevchuk, O. A., \& Matviichuk, O. A. (2019). Modem breeding and cultivation of unpopular fruits and berries in Ukraine. Ukrainian Journal of Ecology, 9(3), 204-213.

Moskalets, T. Z., Vasylkivskyi, S. P., Morgun, B. V., Moskalets, V. I., Moskalets, V. V., \& Rybalchenko, V. K. (2016). New genotypes and technological indicators of winter triticale. Biotechnologia Acta, 9(1), 79-86.

Moskalets, V. V., Grynyk, I. V., Moskalets, T. Z., Frantsishko, V. S., \& Batochenko, V. M. (2020). Metodychni rekomendatsii z vyznachennia ekoloho-adaptyvnoho i produktyvnoho ahrobiopotentsialu deiakukh roslyn, maloposhyrenykh v kultur sadivnytstva Ukrainy [Methodical recommendations to determine ecologicaladaptive and productive agrobio potential of some plants which are minor crops in horticulture of Ukraine]. Centr Uchbovoi Literatury, Kyiv (in Ukrainian)

Moskalets, T. Z., Frantsishko, V. S., Knyazyuk, O. V., Pelekhatyi, V. M., Pelekhata, N. P., Moskalets, V. V., Vovkohon, A. H., Sliusarenko, S. V., Morgun, B. V., Gunko, S. M., Podpriatov, H. I., Voitsekhivskyi, V. I., \& Voitsekhivska, O. V. (2019a). Morphological variability, biochemical parameters of berries different ecotypes Hippophae rhamnoides L. and the possibilities for their targeted use in the food-processing industry. Ukrainian Journal of Ecology, 9(4), 749-764.

Mosyakin, S. L., \& Fedoronchuk, M. N. (1999). Vascular plants of Ukraine. A nomenclatural checklist. Naukova Dumka, Kyiv.

Mrkonjić, Z., Nađpal, J., Beara, I., Aleksić Sabo, V., Četojević-Simin, D., MimicaDukić, N., \& Lesjak, M. (2017). Phenolic profiling and bioactivities of fresh fruits and jam of Sorbus species. Journal of the Serbian Chemical Society, $82(6), 651-664$ 
Nemeth, C. (2015). Sorbus pelsoensis (Sorbus subgenus tormaria), a new species from the surroundings of Lake Balaton, Hungary. Studia Botanica Hungarica, 46, 49-60.

Oddou-Muratorio, S., Demesure-Musch, B., Pélissier, R., \& Gouyon, P.-H. (2004) Impacts of gene flow and logging history on the local genetic structure of a scattered tree species, Sorbus torminalis L. (Crantz). Molecular Ecology, 13, 3689-3702.

Olszewska, M. (2011). In vitro antioxidant activity and total phenolic content of the inflorescences, leaves and fruits of Sorbus torminalis (L.) Crantz. Acta Poloniae Pharmaceutica, 68(6), 945-953.

Olszewska, M., \& Michel, P. (2009). Antioxidant activity of inflorescences, leaves and fruits of three Sorbus species in relation to their polyphenolic composition. Natural Product Research, 23(16), 1507-1521.

Orsanic, M., Drvodelic, D., Jemric, T., Anic, I., \& Mikac, S. (2009). Variability of morphological and biological characteristics of wild service tree (Sorbus torminalis (L.) Crantz) fruits and seeds from different altitudes. Periodicum Biologorum, 111, 495-504.

Paul, M., Hinrichs, T., Janßen, A., Schmitt, H.-P., Soppa, B., Stephan, B.-R., \& Dörflinger, H. (2000). Konzept zur erhaltung und nachhaltigen nutzung forstlicher genressourcen in der Bundesrepublik Deutschland. Forstliche Genressourcen und Forstsaatgutrecht, Neufassung.

Pohrebniak, P. S. (1993). Lisova ekolohiia i typolohiia lisiv [Forest ecology and typology of forests]. Naukova Dumka, Kyiv (in Ukrainian).

Pyttel, P., Kunz, J., \& Bauhus, J. (2011). Age and growth of Wild service tree (Sorbus torminalis (L.) Crantz) in former oak coppice forests in southwest Germany. In: Maaten-Theunissen, M., Spiecker, H., Cartner, H. G., Helle, G., \& Heinrich, I. (Eds.). TRACE - Tree rings in archaeology, climatology and ecology, scientific technical report. GFZ Potsdam, Potsdam. Pp. 64-70.

Pyttel, P., Kunz, J., \& Bauhus, J. (2013). Growth, regeneration and shade tolerance of the wild service tree (Sorbus torminalis (L.) Crantz) in aged oak coppice forests. Trees, 27, 1609-1619.

Raudone, L., Raudonis, R., Gaivelyte, K., \& Gaivelyte, K. (2014). Phytochemical and antioxidant profiles of leaves from different Sorbus L. species. Natural Product Research, 29(3), 1-5.

Rich, T. C. G., Green, D., Houston, L., Lepsı, M., Ludwig, S., \& Pellicer, J. (2014). British Sorbus (Rosaceae): Six new species, two hybrids and a new subgenus. New Journal of Botany, 4(1), 2-12.

Rivers, M., Beech, E., Bazos, I., Bogunić, F., Buira, A., Caković, D., Carapeto, A., Carta, A., Cornier, B., Fenu, G., Fernandes, F., Fraga-Arguimbau, P., Garcia Murillo, P., Lepší, M., Matevski, V., Medina, F., Menezes de Sequeira, M. Meyer, N., Mikoláš, V., Montagnani, C., Monteiro-Henriques, T., Naranjo Suárez, J., Orsenigo, S., Petrova, A., Reyes-Betancort, A., Rich, T., Salvesen P. H., Santana López, I., Scholz, S., Sennikov, A., Shuka, L., Silva, L. F., Thomas, P., Troia, A., Villar, J. L., \& Allen, D. (2019). European Red List of Trees. International Union for Conservation of Nature and Natural Resources, Cambridge and Brussels.

Romanchuk, O. P. (Ed.). (2017). Podillia. Litopys pryrody Natsionalnyy Pryrodnyy Park "Karmeliukove Podillia" [Podillia. Chronicle of nature NNP "Karmeliukove Podillia"]. Prosvita, Chechelnyk (in Ukrainian).
Sennikov, A., \& Kurtto, A. (2017). A phylogenetic checklist of Sorbus s.l. (Rosaceae) in Europe. Memoranda Societatis pro Fauna et Flora Fennica, 93, 2-78.

Shahraji, T. R., Sheikhali, M., \& Pourbabaei, H. (2013). Leaves polymorphism and fruit shapes variation of Sorbus torminalis (L.) Crantz in Hyrcanian forest. Journal of Advanced Laboratory Research in Biology, 4(1), 11-14.

Shelyag-Sosonko, Y. R., Dubina, D. V., Vakarenko, L. P., Movchan, Y. I., Didukh, Y. P., Zahorodniuk, I. V., Popovych, S. Y., Tkach, V. P., \& Mukhalkiv, V. M. (2003). Zberezshennia i nevysnazshlyve vykorystannia bioriznomanittia Ukrainy: Stan ta perspektyvy [Preservation of biological diversity in Ukraine: State and prospects]. Chimdzhest, Kyiv (in Ukrainian).

Shpak, N. P. (2018). Plodonoshennia ta pryrodne ponovlennia Sorbus torminalis (L.) Crantz pid nametom dubovykh nasadzhen u Pivdenno-Podilsomu Lisostepu Ukrainy [Fruiting and natural restoration of Sorbus torminalis (L.) Crantz under the oak stands canopy in the South-Podilsky Forest-Steppe of Ukraine]. Scientific Bulletin of National Forestry University of Ukraine, 28(10), 53-56 (in Ukrainian).

Shpak, N. P. (2019). Monitorynh pryrodnoho vidnovlennia bereky likarskoi v dubovo-grabovykh dibrovakh Pivdenno-Podilskoho Lisostepu Ukrayiny [Monitoring of natural renewal of species Sorbus torminalis (L.) Crantz the conditions south of Podolsk Forest-Steppe of Ukraine]. Scientific Bulletin of National Forestry University of Ukraine, 29(5), 27-30 (in Ukrainian).

Shpak, N. P., Shlapak, V. P., \& Leontiak, H. P. (2017). Osoblyvosti kultyvuvannia nasadzhen duba zvychainoho za uchastiu bereky likarskoi v umovakh Pivdennoho Podillia [Some peculiarities of cultivation of common oak stands involving wild service tree in Southern Podillia]. Scientific Bulletin of National Forestry University of Ukraine, 27(3), 71-74 (in Ukrainian).

Szymura, T. H., Szymura, M., \& Pietrzak, M. (2014). Influence of land relief and soil properties on stand structure of overgrown oak forests of coppice originwith Sorbus torminalis. Dendrobiology, 71, 49-58.

Termena, B. K., \& Budzhak, V. V. (1997). Reproduktyvnyi potentsial Sorbus torminalis (L.) Crantz. v umovakh Pivnichnoi Bukovyny [Reproductive potential of Sorbus torminalis (L.) Crantz. in the conditions of Northern Bukovyna]. Naukova Dumka, Kyiv (in Ukrainian).

Thomas, P. A. (2017). Biological flora of the British Isles: Sorbus torminalis. Journal of Ecology, 105, 1806-1831.

Tkachyk, S. O. (Ed.). (2016). Metodyka provedennia ekspertyzy sortiv roslyn hrupy lisovyh na vidminnist, odnoridnist i stabilnis [Guidelines for the conduct of tests of plant varieties of the forest group for distinctness, uniformity and stability] Nilan-LOD, Vinnytsia (in Ukrainian).

Ulaszewski, B., Sandurska, E., Sztupecka, E., \& Burczyk, J. (2017). The complete chloroplast genome sequence of wild service tree Sorbus torminalis (L.) Crantz. Conservation Genetics Resources, 9, 419-422.

Veberic, R., Slatnar, A., Bizjak, J., Stampar, F., \& Mikulic-Petkovsek, M. (2015). Anthocyanin composition of different wild and cultivated berry spesies. Food Science and Technology, 60, 509-517.

Werres, J. M. (2018). Zur tierökologischen Bedeutung der Elsbeere (Sorbus torminalis L. Crantz). Rheinische Friedrich-Wilhelms-Universität, Bonn.

Zwierzyński, J., \& Bednorz, L. (2012). Regional programme of conservation and restitution of Sorbus torminalis in the territory of the regional directorate of the state forests in Piła in 2010-2013. Nauka, Przyroda, Technologie, 6(3), 4-6. 